\title{
FITUR KESALAHAN PENGGUNAAN EJAAN YANG DISEMPURNAKAN DALAM MAKALAH MAHASISWA
}

\author{
Trinil Dwi Turistiani \\ Universitas Negeri Surabaya \\ Email: trinildwi65@yahoo.co.id
}

\begin{abstract}
Abstrak: Tujuan penelitian ini untuk mendeskripsikan aneka jenis kesalahan penggunaan ejaan, tingkat keseriusan kesalahan, dan faktor-faktor penyebab terjadinya kesalahandalam makalah mahasiswa. Hasil penelitian ini diharapkan bermanfaat bagi mahasiwa, dosen mata kuliah Bahasa Indonesia Keilmuan, dan dosen pada umumnya.Berdasarkan sifat dan karakteristik masalah yang dikaji,penelitian ini menggunakan pendekatan deskriptif kualitatif karena berusaha menggambarkan secara objektif atau apa adanyakesalahan penggunaan ejaan pada makalahmahasiswa.Data penelitian berupa bahasa tulisan atau kalimat yang mengandung kesalahan penggunaan ejaan.Sumber data penelitian ini berupa 21 makalah yang ditulis oleh mahasiswa Jurusan Pendidikan Olahraga FIKUnesa.Teknik yang digunakan untuk mengumpulkan data dalam penelitian ini berupa teknik dokumentatif.Teknik analisis data menggunakan prosedur kerja analisis kesalahan berbahasa meliputi, (1) identifikasi data, (2) klasifikasi data, dan (3) penentuan frekuensi kesalahan. Hasil penelitian ini berupa temuan beberapa jenis kesalahan penggunaan ejaan, meliputi kesalahan penggunaan tanda baca (tanda titik dan tanda koma), kesalahan pemakaian huruf (huruf miring), dan kesalahan penulisan kata (gabungan kata, kata berimbuhan, kata depan, partikel, dan lambang bilangan). Dilihat dari frekuensi dan persebaran kesalahan dapat disimpulkan bahwa kesalahan pemakaian tanda baca dan penulisan kata merupakan bentuk kesalahan yang cukup serius. Apabila dicermati kesalahan-kesalahan tersebut merupakan kesalahan intrabahasa yang disebabkan oleh ketidaktahuan akan pembatasan kaidah dan penerapan kaidah yang tidak sempurna, yakni kaidah ejaan yang disempurnakan (EYD)
\end{abstract}

Kata kunci: kesalahan penulisan, penerapan kaidah, tanda baca

Abstract: The paper is to describe various kinds of errors in making use of spelling, the levels of errors, and some factors which affect the errors in students' paperworks. The result of investigation is hoped to give significant contributions toward students, teachers of the subject of Bahasa Indonesia Keilmuan, and general teachers. Based on types and characteristics of the problems, the research uses descriptive qualitative, since it describes various kinds of spelling on students' paperworks objectively. The data of the research denote written language which comprises mistakes on their spelling. The source of the research is 21 paperworks of students of Sports Education Department of The State University of Surabaya. In collecting the data, the research uses documentary technique. The data analysis technique uses error analysis of language which comprises (1) data identification, (2) data classification, (3) the notification of error frequency. The result of the analysis denote some errors in spelling, which includes punctuations, errors in making use of italic words and mistyping of some words (combination of words, affixes, particles, and numbers). In terms of frequencies and distribution of errors, it can be concluded that the errors in making use of punctuation and word's spelling are serious errors. Looking at those errors, they are the 
effects if interlanguage which caused by students' lack of knowledge of the pattern and the application of sophisticated spelling or known as EYD.

Keywords: typing error, the application of the rules, punctuation

\section{Pendahuluan}

Perguruan tinggi merupakan salah satu tempat bermukimnya anggota masyarakat ilmiah. Kehidupan masyarakat ilmiah itu tidak dapat dilepaskan dari kegiatan penulisan karya ilmiah. Sebagai anggota masyarakat ilmiah, mahasiswa perlu memiliki kemampuan menulis. Kemampuan ini fungsional sifatnya bagi pengembangan diri mereka, baik dalam rangka kelanjutan studinya, maupun untuk keperluan dirinya saat terjun ke dalam masyarakat. Dengan kemampuan menulis ini, mereka dapat mengomunikasikan gagasan, pikiran, penghayatan serta pengalamannya ke berbagai pihak secara baik dan tepat, terlepas dari ikatan waktu dan tempat. Kemampuan menulis ini sangat dibutuhkan dalam masyarakat yang dinamis dan berkembang.

Kemampuan menulis secara baik dan benar merupakan modal penting bagi seorang mahasiswa, baik kepentingan yang berkaitan dengan tugas akademis maupun di masyarakat. Mahasiswa yang mampu menulis dengan runtut dan mengikuti kaidah bahasa akan lebih mudah dalam mengerjakan tugas, makalah, dan menyusun skripsi daripada mahasiswa yang tidak dapat menulis secara runtut, logis, dan tidak memahami kaidah bahasa. Setelah berada di masyarakat kemampuan menulis dengan baik dan benar akan membantu dalam melaksanakan tugas sehari-hari.

Dalam konteks yang lebih luas kemampuan menulis sangat penting artinya bagi dunia pengembangan ilmu pengetahuan dan teknologi. Perkembangan iptek pasti memerlukan penulisan hasilhasil penelitian yang harus dikomunikasikan kepada orang lain dalam bentuk bahasa tulis yang mempunyai nilai dokumentasi sangat kuat. Di sini semua orang terlibat, terutama para ilmuwan (mahasiswa), dituntut memiliki kemampuan menulis dengan bahasa yang efektif. Tidak berbeda dengan bahasa-bahasa lain di dunia, dalam bahasa Indonesia telah dibakukan seperangkat kemudahan untuk menyusun karya tulis yang efektif. Karya tulis ilmiah yang efektif mengharuskan dipakainya bahasa yang tepat, singkat, jelas, teratur, dan resmi.

Makalah merupakan salah satu bentuk karya ilmiah. Untuk menghasilkan suatu makalah yang baik dituntut adanya keterampilan-keterampilan tertentu bagi penulisnya. Salah satu keterampilan itu ialah keterampilan bahasa. Penguasaan keterampilan bahasa meliputi penguasaan ejaan, penguasaan pembentukan kata, penguasaan pemilihan kata, penguasaan penyusunan kalimat efektif dan penguasaan penyusunan paragraf yang utuh (Yulianto, 2003:1). Semua penulis makalah, dalam hal ini mahasiswa, dituntut untuk mematuhi aturan-aturan tersebut.

Bahasa yang digunakan dalam makalah merupakan bahasa ragam tulis. Bahasa ragam tulis berbeda dengan bahasa ragam lisan yang masih dibantu oleh sikap tubuh, isyarat, dan mimik penuturnya manakala terjadi perbedaan tanggapan atas pelisanan sesuatu. Bahasa ragam tulis dalam makalah harus jelas, lugas, dan komunikatif supaya pembaca dengan mudah memahami isinya (Ahmadi, dkk., 2011:52).

Jelas berarti bahwa bahasa yang digunakan secara jelas memperlihatkan unsur-unsur kalimat (subjek, predikat, objek, pelengkap, dan keterangan). Lugas berarti 
bahwa bahasa yang digunakan tidak menimbulkan tafsiran ganda atau ambigu. Komunikatif berarti bahwa apa yang ditangkap pembaca sama dengan maksud penulisnya. Wacana yang komunikatif tersaji secara logis dan sistematis. Kelogisan itu terlihat dari hubungan antarbagian dalam kalimat, antarkalimat dalam paragraf, dan antarparagraf dalam wacana.

Penggunaan bahasa dalam penulisan karya ilmiah, dalam hal ini makalah dapat diperhatikan atas beberapa dasar di antaranya ialah ragam. Ragam bahasa ilmiah memiliki ciri-ciri cendekia, lugas, jelas, formal, objektif, konsisten, dan berangkat dari gagasan yang faktual atau nyata, bukan rekaan (R.Soedradjad, http://elcom.umy.ac.id/elschool/muallimin muhammadiyah/file.php/1/materi/bahasaindonesia/bab-3-bahasa.pdf). Dalam kaitannya dengan ragam bahasa perlu memperhatikan (i) diksi, (ii) penyusunan kalimat efektif, dan (iii) paragraf yang kohesif dan koheren. Kaidah ejaan merupakan tata cara penulisan yang mengimplementasikan sistem pengelolaan bahasa untuk menjadi bahasa yang baku.

Pada kenyataannya, mahasiswa masih sering melakukan kesalahan dengan atau tanpa sengaja dalam menulis makalah. Mereka menggunakan bahasa yang tidak resmi dan ejaan yang tidak sesuai dengan kaidah. Penelitian yang dilakukan oleh Mardan (2000) tentang analisis kesalahan berbahasa Indonesia dalam naskah asli artikel mahasiswa, menghasilkan suatu temuan bahwa para mahasiswa masih mengalami kesulitan dalam penggunaan ejaan, pemilihan dan pemakaian kata, dan penyusunan kalimat. Hal ini bisa dilihat dari besarnya jumlah kesalahan yang dibuat pada saat menulis artikel. Jumlah kesalahan ejaan paling banyak, bila dibandingkan dengan jumlah kesalahan aspek yang lain.

Masalah ejaan tampaknya amat sederhana, karena itulah mahasiswa sering melupakannya. Pedoman ejaan yang disempurnakan, kamus, dan tata bahasa merupakan rambu-rambu untuk menuliskan bahasa tulis baku. Ketepatan pengguanaan ejaan bisa dijadikan ukuran sejauh mana pemahaman bahasa seseorang, bahkan dijadikan ukuran sejauh mana seseorang 'melek bahasa' (Putrayasa, 2007: 21). Ejaan adalah keseluruhan peraturan bagaimana melambangkan bunyi ujaran dan bagaimana hubungan antara lambang-lambang itu (pemisahan dan penggabungan dalam suatu bahasa).

Melakukan kesalahan berbahasa dalam pembelajaran itu suatu hal yang wajar. Seperti yang diungkapkan Brown (2004:164) bahwa dalam pembelajaran selalu terjadi kesalahan. Sejalan dengan pendapat tersebut Dulay et.al (1982:164) mengungkapkan bahwa orang tidak mungkin dapat mempelajari bahasa tanpa membuat kesalahan secara sistematik. Corder (1985:5) meyakini bahwa pada setiap orang yang belajar bahasa pastilah pernah melakukan kesalahan.Keyakinan itu senada dengan pendapat Ancker (2000), "making mistakes or errors is a natural process or learning and must be considered as part of cognition"'(dalam Saadiyah Darus dan Kaladevi Subramaniam, 2009 : 487).

Kesalahan berbahasa adalah terjadinya penyimpangan kaidah dalam tindak berbahasa, baik secara lisan maupuin tertulis. Penyimpangan itu dibedakan atas kekeliruan (mistake) dan kesalahan (error). Kekeliruan adalah penyimpangan pemakaian bahasa yang terjadi tidak secara sistematis. Kekeliruan mengacu pada language performance yang terjadi karena keterbatasan ingatan, mengeja dalam lafal, keseleo lidah, tekanan emosional, dan sebagainya. Sebaliknya, kesalahan adalah penyimpangan dalam pemakaian bahasa yang terjadi secara sistematis. Kesalahan bersifat konsisten dasn menggambarkan kemampuan si penulis pada tahap tertentu 
(Baradja, 1981:12). Dengan demikian, kesalahan mengacu pada language competence.

Pembedaan antara kekeliruan dan kesalahan sangat penting, tetapi acap kali sulit menentukan sifat dan hakikat suatu penyimpangan penggunaan bahasa tanpa mengadakan analisis yang cermat (Suwandi, 2008: 165). Dalam penelitian ini, pengidentifikasian penyimpangan atas kekeliruan dan kesalahan lebih didasarkan pada sistematis tidaknya penyimpangan tersebut.

Agar diperoleh data tentang berbagai macam bentuk kesalahan penggunaan ejaan yang dilakukan mahasiswa, perlu dilakukan analisis kesalahan. Dari data kesalahan yang diperoleh, selanjutnya dicarikan pemecahan berdasarkan sumber kesalahan yang ada.Pengetahuan tentang sumber kesalahan dapat digunakan untuk melakukan tindakan yang mengarah kepada upaya tindak lanjut yang berupa terapi kesalahan dalam bentuk tindakan remedial. Dengan demikian, faktor-faktor penyebab kesalahan itu dapat diupayakan untuk dikendalikan. Seluruh proses tersebut memerlukan data yang faktual, yakni data kesalahan penggunaan ejaan yang dilakukan oleh mahasiswa.

Banyak keuntungan yang bisa diambil dari kegiatan analisis kesalahan berbahasa, dalam hal ini kesalahan penggunaan ejaan, terutama yang berhubungan dengan kegiatan pengajaran bahasa dan pelatihan atau pembinaan bahasa (Suwandi, 2008:169). Dengan analisis kesalahan dapat dipahami dan diungkapkan berbagai jenis kesalahan penggunaan ejaan yang dibuat oleh mahasiswa dan latar belakang serta faktor penyebabnya. Hal itu dapat digunakan untuk memperbaiki kesalahan sejenis pada masa yang akan datang. Dengan demikian, kegiatan analisis kesalahan penggunaan ejaan diharapkan bermanfaat bagi perkuliahan Bahasa Indonesia Keilmuan, terutama untuk materi ajar Penulisan Karya Ilmiah.

Hal yang perlu dianalisis selanjutnya adalah tingkat keseriusan kesalahan penggunaan ejaan yang dilakukan oleh mahasiswa. Tingkat keseriusan kesalahan penggunaan ejaan didasarkan pada dua hal, yaitu frekuensi kesalahan dan persebaran kesalahan. Hal ini perlu dilakukan karena analisis kesalahan bersifat pedagogis, yakni kegiatan yang bermuara pada upaya peningkatan kemampuan menggunakan ejaan yang disempurnakan pada penulisan karya ilmiah.

\section{Metode Penelitian}

Penelitian ini bertujuan untuk mengkaji kesalahan penggunaan ejaan dalam makalah mahasiswa. Berdasarkan sifat dan karakteristik masalah yang dikaji, penelitian ini menggunakan pendekatan deskriptif kualitatif. Pendekatan ini digunakan dengan pertimbangan bahwa sumber data utama penelitian ini ialah makalah yang merupakan bahasa tulis. Dengan demikian, pendekatan ini digunakan untuk menggambarkan secara objektif atau apa adanya kesalahan penggunaan ejaan pada makalah mahasiswa. Data penelitian berupa bahasa tulisan yang mengandung kesalahan penggunaan ejaan. Sumber data penelitian ini adalah makalah yang ditulis oleh mahasiswa Jurusan Pendidikan Olahraga Angkatan 2010/A Fakultas Ilmu Keolahragaan Universitas Negeri Surabaya. Makalah yang dijadikan sebagai sumber data sebanyak 21 buah, dengan pertimbangan makalah tersebut mempunyai kesalahan paling banyak.

$$
\text { Langkah-langkah dalam }
$$

mengumpulkan data yaitu, (1)data dikumpulkan dari makalah mahasiswa Jurusan Pendidikan Olahraga Fakultas Ilmu Keolahragaan Universitas Surabaya angkatan 2010/A, (2)Pengambilan makalah sebagai sumber data dibatasi karena 
makalah-makalah tersebut mempunyai kecenderungan kesalahan yang sama.Dari 41 makalah diambil 21 yang mempunyai kesalahan terbanyak. Jumlah ini dianggap sudah dapat mewakili bentuk-bentuk kesalahan berbahasa yang dilakukan oleh mahasiswa.

Teknik pengumpulan data terkait erat dengan bagaimana cara memperoleh data. Teknik yang digunakan untuk mengumpulkan data dalam penelitian ini berupa teknik dokumentatif. Teknik ini digunakan karena data yang dicari peneliti sudah tersedia dalam bentuk data bahasa tulisan yang berasal dari makalah mahasiswa. Dalam teknik dokumentatif, peneliti berperan sebagai instrumen. Teknik analisis data menggunakan prosedur kerja analisis kesalahan berbahasa meliputi,(1) identifikasi data, (2) klasifikasi data, dan (3) penentuan frekuensi kesalahan.

\section{Hasil dan Pembahasan}

\section{Jenis-jenis Kesalahan Penggunaan Ejaan}

Dalam penelitian ini ditemukan kesalahan penggunaan ejaan antara lain terlihat pada kesalahan pemakaian tanda baca (tanda koma dan tanda titik), pemakaian huruf (miring), dan penulisan kata (gabungan kata, kata berimbuhan, kata depan, partikel, angka dan lambang bilangan).

\section{a. Kesalahan Pemakaian Tanda Baca}

Kesalahan pemakaian tanda baca yang ditemukan sebanyak 104 data meliputi, kesalahan pemakaian tanda koma (,) dan tanda titik (.).

\section{1) Kesalahan Pemakaian Tanda Koma} (,)

Berkaitan dengan kesalahan pemakaian tanda koma, dalam penelitian ini ditemukan sebanyak 68 data kesalahan. Kesalahan pemakaian tanda koma terjadi karena penulis melakukan hal-hal seperti berikut. a) Tanda koma tidak dipakai di antara unsur-unsur suatu perincian (13 data kesalahan).

b) Tanda koma tidak dipakai untuk memisahkan anak kalimat dari induk kalimat, jika anak kalimat itu mendahului induk kalimatnya (3 data kesalahan).

c) Tanda koma dipakai untuk memisahkan anak kalimat dari induk kalimat jika anak kalimat itu mengiringi induk kalimatnya (6 data kesalahan).

d) Tanda koma tidak dipakai di belakang kata atau ungkapan penghubung antarkalimat yang berada di awal kalimat (39 data kesalahan).

e) Tanda koma tidak dipakai untuk memisahkan kalimat setara yang satu dari kalimat setara berikutnya yang didahului oleh kata tetapi atau melainkan (3 data kesalahan).

f) Tanda koma tidak dipakai untuk mengapit keterangan tambahan yang sifatnya tidak membatasi (4 data kesalahan).

Contohkesalahan penggunaan ejaan dapat dilihat berikut ini.

(1) ... seperti telur, susu, daging, unggas, ikan_dan kerang.(16/E/PW/5)

(2) Bila atlet mengalami... ringan semisal terjadi robekan atau tarikan ... diakibatkan_ maka pertolongan pertama adalah menggunakan metode RICE.(24/E/KCD/9)

(3) ... kelebihan latihan fisik, sehingga menyisakan radikal bebas yang menumpuk dalam tubuh. (14/E/MA/5)

(4) Jadi_manusia tidak bisa hidup tanpa gula.(6/E/YW/2)

(5) Olahraga ini menyehatkan_tetapi jika berlebihan akan menurunkan sistem ....(3/E/DRB/1)

(6) ... kecepatan yang tinggi_ baik perorangan maupun ganda Anda mengejarshuttlecock yang (21/E/KCD/9) 
Berikut ini merupakan perbaikan data-data tersebut.

(1a) ... seperti telur, susu, daging, unggas, ikan, dan kerang.

(2a) Bila atlet mengalami... ringan, semisal terjadi robekan atau tarikan ...diakibatkan, pertolongan pertama adalah menggunakan metode RICE.

(3a) ... kelebihan latihan fisik sehingga menyisakan radikal bebas yang menumpuk dalam tubuh.

(4a) Jadi, manusia tidak bisa hidup tanpa gula.

(5a) Olahraga ini menyehatkan, tetapi jika berlebihan akan menurunkan sistem ....

(6a) ... kecepatan yang tinggi, baik perorangan maupun ganda, Anda mengejar shuttlecock yang ....

\section{2) Kesalahan Pemakaian Tanda Titik (.)}

Dalam hal pemakaian tanda titik, ditemukan sebanyak 36 data kesalahan. Kesalahan ini terjadi karena penulis melakukan hal-hal berikut:

a. Tanda titik tidak dipakai pada akhir kalimat yang bukan pertanyaan atau seruan (31 data kesalahan).

b. Tanda titik dipakai di belakang angka atau huruf dalam suatu bagan atau ikhtisar, padahal angka atau huruf itu merupakan yang terakhir dalam deretan angka dan huruf (5data kesalahan).

Berikut ini merupakan beberapa contoh data yang menunjukkan kesalahan jenis tersebut.

(7) ... yang telah diperoleh dapat diambil kesimpulan sebagai berikut:(36/E/PW/13)

(8) 6.1. Kram Otot (36/E/MA/8)

Berikut ini merupakan perbaikan data-data tersebut.

(7a) ... yang telah diperoleh dapat diambil kesimpulan sebagai berikut.

(8a) 6.1 Kram Otot

\section{3) Kesalahan Pemakaian Huruf}

Kesalahan pemakaian huruf yang ditemukan adalah kesalahan pemakaian huruf miring. Berkaitan dengan kesalahan tersebut, dalam penelitian ini ditemukan sebanyak 23 data kesalahan.

Penulis makalah tidak memakai huruf miring untuk menuliskan kata nama ilmiah atau ungkapan asing kecuali yang telah disesuaikan ejaannya. Data kesalahan yang ditemukan sebanyak 21 data. Berikut ini merupakan beberapa data kesalahan yang menunjukkan jenis kesalahan tersebut.

(9) Warming up adalah aktivitas yang berisi gerakan-gerakan .... (7/E/PAS/3)

(10) ..., perlu juga melakukan pereganganatau stretching. (18/E/PAS/5)

Berikut merupakan perbaikan datas kesalahan tersebut.

(9a) Warming upadalah aktivitas yang berisi gerakan-gerakan ....

(10a) ..., perlu juga melakukan peregangan atau stretching.

Huruf miring tidak dipakai untuk menuliskan nama buku, majalah, dan surat yang dikutip dalam tulisan. Ada dua data kesalahan yang ditemukan. Berikut ini merupakan data yang menunjukkan jenis kesalahan tersebut.

(11) Direktur gizi.1992. Daftar Komposisi Bahan Makanan. Jakarta: Bhatara. (21/E/MR/6)

(12) Erman.2007. Dasar-dasar Biokimia Olahraga. Surabaya: Unesa Unipress.(22/E/MR/6)

Perbaikan kesalahan tersebut seperti di bawah ini.

(11a) Direktur gizi. 1992. Daftar

Komposisi Bahan Makanan. Jakarta: Bhatara.

(12a) Erman. 2007. Dasar-dasar Biokimia

Olahraga. Surabaya: Unesa Unipress.

\section{4) Kesalahan Penulisan Kata}

Kesalahan penulisan kata yang ditemukan meliputi kesalahan penulisan 
gabungan kata, kata berimbuhan, kata depan, partikel, dan angka dan lambang bilangan. Beberapa kesalahan tersebut diuraikan sebagai berikut.

\section{a) Kesalahan Penulisan Gabungan kata}

Kesalahan yang dilakukan penulis makalah dalam hal penulisan gabungan kata yakni, gabungan kata yang sudah dianggap sebagai satu kata tidak dituliskan serangkai. Berikut ini merupakan data kesalahan yang menunjukkan jenis kesalahan tersebut.

(13) Kandungan buah kersen lebih baik dari pada minuman isotonik yang saat iniberedar di pasaran.(10/E/DPHP/3)

(14) ..., sehingga kami dapat menyelesaikan makalah tentang olah raga dan kesehatan ini dengan baik.(1/E/DBP/ii)

Data kesalahan dapat diperbaiki sebagai berikut.

(13a) yang saat ini beredar di pasaran.Kandungan buah kersen lebih baik daripada minuman isotonik

(14a) ..., sehingga kami dapat menyelesaikan makalah tentang olahraga dan kesehatan ini dengan baik.

Selain itu, jika salah satu unsurnya tidak dapat berdiri sendiri sebagai satu kata yang mengandung arti penuh, hanya muncul dalam kombinasi, unsur itu harus dituliskan serangkai dengan unsur lainnya (Arifin dan Tasai, 2009: 188). Berikut ini merupakan data yang menunjukkan jenis kesalahan tersebut.

(15) Sebagai contoh, karakter cabang olahraga sepak bola yang lebih banyak terjadi kontak fisik antar pemain, .... ( 4/E/PAS/1)

Data kesalahan tersebut dapat diperbaiki sebagai berikut.

(15a) Sebagai contoh, karakter cabang olah raga sepak bola yang lebihbanyak terjadi kontak fisik antarpemain,....

\section{b) Kesalahan Penulisan Kata Berimbuhan}

Kesalahan yang ditemukan dalam hal penulisan kata berimbuhan, terjadi karena tidak menuliskan serangkai kata dasar yang mendapatkan imbuhan berupa awalan dan atau akhiran. Berikut ini merupakan data yang mewakili data kesalahan tersebut.

(16) ... aktivitas yang di lakukan oleh seseorang terutama yang memang pekerjaan....(12/E/DPHP/3)

(17) Efek yang di timbulkan bila isotonik dikonsumsi secara berlebihan .... (14/E/DPHP/4)

Berikut ini merupakan perbaikan data-data tersebut.

(16a) ...aktivitas yang dilakukan oleh seseorang terutama yang memang pekerjaan ....

(17a) Efek yang ditimbulkan bila isotonik dikonsumsi secara berlebihan yaitu ....

\section{c) Kesalahan Penulisan Kata Depan}

Dalam hal penulisan kata depan, ditemukan kesalahan penulisan kata depan $d i$ dan ke.Penulis makalah melakukan kesalahan dengan menuliskan kata depan $d i$ secara tidak terpisah dari kata yang mengikutinya. Berikut ini merupakan data kesalahan yang menunjukkan kesalahan jenis tersebut.

(18)Diluarjaringan tubuh kekurangan pasokan glukosa dapat terhambat .... (11/E/YW/2)

(19) Hal ini didukung dengan intensifnya informasi yang beredar dimasyarakat. (5/E/DPHP/2)

Berikut ini merupakan perbaikan data-data tersebut.

(18a) Di luarjaringan tubuh kekurangan pasokan glukosa karena terhambat ....

(19a) Hal ini didukung dengan intensifnya informasi yang beredar

dimasyarakat 
Penulis makalah juga melakukan kesalahan dengan menuliskan kata depan ke secara tidak terpisah dari kata yang mengikutinya. Berikut ini merupakan data kesalahan yang menunjukkan kesalahan jenis tersebut.

(20) Setelah itu endapan yang ada pada jus tersebut naik dengan sendirinya kepermukaanair. (28/E/DPHP/12)

(21) ... kondisi anak, dan dapat mendorong kearah perubahan tersebut. (2/E/DRB/1)

Berikut ini merupakan perbaikan data-data tersebut.

(20a) Setelah itu endapan yang ada pada jus tersebut naik dengan sendirinyake permukaan air.

(21a) ... kondisi anak, dan dapat mendorong kearah perubahan tersebut.

\section{d) Kesalahan Penulisan Partikel}

Dalam hal penulisan partikel, kesalahan yang ditemukan dalam penelitian ini mencakup kesalahan penulisan partikel pun dan partikel per. Kesalahan penulisan partikel pun terjadi karena subjek penelitian membuat kesalahan dengan menuliskan partikel pun secara tidak terpisah dari kata yang mendahuluinya. Ada beberapa data kesalahan yang ditemukan, seperti di bawah ini.

(22) Selain bugar merekapun telah melakukan tindakan preventif. (20/ $\mathrm{E} / \mathrm{STH} / 4)$

(23) Hal ini mengakibatkan ekskresi air juga bertambah, perasaan hauspun bertambah.(31/E/PW/10)

(24) Dengan demikian siapapun yang berolahraga dengan baik dan benar .... (21/ E/STH/4)

(25) Harus diakui, apapun cabang olahraganya pasti berpotensi cedera.(5/E/PAS/1)

Pada data (22) sampai dengan (25) terdapat kesalahan penulisan partikel pun. Penulisan pun pada kata merekapun, hauspun, siapapun, dan apapun dituliskan serangkai. Kata-kata tersebut seharusnya dituliskan terpisah dari partikel pun yang melekatinya. Dengan demikian, data kesalahan dapat diperbaiki sebagai berikut.

(22a) Selain bugar, mereka pun telah melakukan tindakan preventif.

(23a) Hal ini mengakibatkan ekskresi air bertambah, perasaan haus pun bertambah.

(24a) Dengan demikian, siapa pun yangberolahraga dengan baik dan benar ....

(25a) Harus diakui, apa pun cabang olahraganya pasti berpotensi cedera.

Dalam hal penulisan partikel per,penulis makalah melakukan kesalahan dengan menuliskan partikel per secara tidak terpisah dari bagian kalimat yang mendahuluinya atau mengikutinya. Data kesalahan yang menunjukkan kesalahan jenis tersebut adalah sebagai berikut.

(26) ... secara teratur tiga hingga lima kali perminggu pada hari yang .... (15/E/STH/3)

Pada data (26) partikel per dituliskan serangkai dengan bagian kalimat yang mengikutinya. Partikel per yang melekat pada kata minggu seharusnya dituliskan terpisah dari kata atau bagian kalimat lainnya. Berikut ini merupakan perbaikan data tersebut.

(26a) ... secara teratur tiga hingga lima kali perminggu pada hari yang ....

\section{e) Kesalahan Penulisan Lambang Bilangan \\ Kesalahan penulisan lambang} bilangan yang ditemukan dalam penelitian, yakni lambang bilangan yang dapat dinyatakan dengan satu atau dua kata tidak dituliskan dengan huruf. Berikut ini merupakan data yang menunjukkan jenis kesalahan tersebut.

(27) ... dan penggantian glikogen memerlukan waktu lebih dari 2 hari.(13/E/KCD/4) 
(28) ... bila dilakukan 3 kali dalam seminggu dalam jangka waktu 1 bulan.(17/E/STH/4)

(29) ..., gerakan tersebut dilakukan sampai dengan 20 hitungan. (12/E/PAS/4)

(30) ... selama 6 bulan akan menghasilkan peningkatan kemampuan optimal. (18/E/STH/4)

Pada data (27) sampai dengan (30) terdapat kesalahan penulisan lambang bilangan, baik lambang bilangan yang dapat dinyatakan dengan satu kata maupun dengan dua kata. Lambang bilangan 2, 3, 1, 20, dan 6 tidak dituliskan dengan huruf. Seharusnya, lambang bilangan tersebut dituliskan dengan huruf karena dapat dinyatakan dengan satu atau dua kata, dan bilangan tersebut juga bukan merupakan perincian atau pemaparan. Berikut ini merupakan perbaikan data-data tersebut.

(27a)... dan penggantian glikogen memerlukan waktu lebih dari dua hari.

(28a) ... bila dilakukan tiga kali dalam seminggu dalam jangka waktu satu bulan.

(29a) ..., gerakan tersebut dilakukan sampai dengan dua puluh hitungan.

(30a)... selama enam bulan akan menghasilkan peningkatan kemampuan optimal.

Kesalahan lain yang juga ditemukan dalam penelitian yakni lambang bilangan pada awal kalimat tidak ditulis dengan huruf. Data kesalahan yang menunjukkan jenis kesalahan tersebut seperti berikut.
(31) 4 prinsip penanganan cedera otot yang benar. $(18 / \mathrm{E} / \mathrm{KCD} / 6)$

(32) 6 langkah mudah mencegah cedera bermain bulu tangkis.

(33) 3 macam perubahan kardiovaskuler yang dialami oleh organ tubuh .... (37/E/MA/6)

Penulisan lambang bilangan pada data-data di atas tidak tepat. Lambang bilangan 4 (31), 6 (32), dan 3 (33) tidak ditulis dengan huruf. Seharusnya, lambang bilangan pada awal kalimat ditulis dengan huruf. Dalam EYD dijelaskan, jika perlu susunan kalimat diubah sehingga bilangan yang tidak dapat dinyatakan dengan satu atau dua kata tidak terdapat pada awal kalimat. Dengan demikian, data kesalahan tersebut dapat diperbaiki sebagai berikut.

(31a) Empatprinsip penanganan cedera otot yang benar.

(32a) Enam langkah mudah mencegah cedera bermain bulu tangkis.

(33a) Tiga macam perubahan kardiovaskuler yang dialami oleh organ tubuh ...

\section{Tingkat Keseriusan Kesalahan}

Hal penting yang perlu dijelaskan setelah pendeskripsian jenis-jenis kesalahan penggunaan ejaan, adalah tingkat keseriusan kesalahan tersebut. Tingkat keseriusan kesalahan penggunaan ejaan didasarkan pada dua hal, yaitu frekuensi kesalahan dan persebaran kesalahan. Untuk memudahkan perhitungan frekuensi dan persebaran kesalahan perlu dibuat tabel distribusi kesalahan seperti di bawah ini. 
Tabel 1. Distribusi Kesalahan Ejaan

\begin{tabular}{|c|c|c|c|c|c|c|}
\hline No & $\begin{array}{c}\text { Kode } \\
\text { Makalah }\end{array}$ & $\begin{array}{c}\text { Pemakaian } \\
\text { Tanda Baca }\end{array}$ & $\begin{array}{c}\text { Pemakaian } \\
\text { Huruf }\end{array}$ & $\begin{array}{c}\text { Penulisan } \\
\text { Kata }\end{array}$ & Jml & Persentase \\
\hline 1 & KH & 5 & 1 & 1 & 7 & $3,03 \%$ \\
\hline 2 & YW & 6 & 2 & 5 & 13 & $5,62 \%$ \\
\hline 3 & DPHP & 4 & - & 9 & 13 & $5,62 \%$ \\
\hline 4 & PW & 12 & 1 & 6 & 19 & $8,23 \%$ \\
\hline 5 & PAS & 1 & 4 & 7 & 12 & $5,20 \%$ \\
\hline 6 & DBP & 4 & - & 6 & 10 & $4,33 \%$ \\
\hline 7 & IJ & 7 & 4 & 1 & 12 & $5,20 \%$ \\
\hline 8 & MRR & 3 & 1 & 6 & 10 & $4,33 \%$ \\
\hline 9 & MA & 6 & 1 & 2 & 9 & $3,90 \%$ \\
\hline 10 & RMR & 10 & 1 & 5 & 16 & $6,93 \%$ \\
\hline 11 & KCD & 6 & - & 7 & 13 & $5,62 \%$ \\
\hline 12 & DRB & 4 & 3 & 4 & 11 & $4,76 \%$ \\
\hline 13 & MR & 3 & 2 & 7 & 12 & $5,20 \%$ \\
\hline 14 & A & 4 & - & 6 & 10 & $4,33 \%$ \\
\hline 15 & STH & 4 & 1 & 10 & 15 & $6,50 \%$ \\
\hline 16 & HNP & 2 & 1 & 5 & 8 & $3,46 \%$ \\
\hline 17 & FS & 6 & - & 3 & 9 & $3,90 \%$ \\
\hline 18 & ANR & 2 & - & 4 & 6 & $2,60 \%$ \\
\hline 19 & WSN & 8 & - & 5 & 13 & $5,62 \%$ \\
\hline 20 & MAS & 5 & 1 & 1 & 7 & $3,03 \%$ \\
\hline 21 & MI & 2 & - & 4 & 6 & $2,60 \%$ \\
\hline & Jumlah & 104 & 23 & 104 & 231 & $100 \%$ \\
\hline & Frekuensi & $45 \%$ & $10 \%$ & $45 \%$ & $100 \%$ & \\
\hline & Persebaran & $100 \%$ & $62 \%$ & $100 \%$ & & \\
\hline & & & & & & \\
\hline
\end{tabular}

Dilihat dari frekuensi munculnya kesalahan, dari 21 makalah yang dianalisis dalam penelitian ditemukan 231 data kesalahan. Kesalahan penggunaan tanda baca sebanyak 104 (45\%), meliputi kesalahan pemakaian tanda koma (,) 68 $(29,4 \%)$ dan kesalahan pemakaian tanda titik (.) 36 (15,6\%). Kesalahan pemakaian huruf, dalam hal ini pemakaian huruf miring sebanyak 23 (10\%). Kesalahan penulisan kata sebanyak 104 (45\%), meliputi kesalahan penulisan gabungan kata $8(3,4 \%)$, penulisan kata berimbuhan $31(13,4 \%)$, penulisan kata depan 45 $(19,5 \%)$, penulisan partikel $9(3,9 \%)$, dan penulisan lambang bilangan 11 (4,8\%). Dengan demikian, frekuensi kemunculan kesalahan pemakaian tanda baca sama tingginya dengan kesalahan penulisan kata, yaitu sebanyak 104 (45\%).

Dari beberapa aspek kesalahan penggunaan ejaan yang dianalisis, kesalahan pemakaian tanda koma mempunyai frekuensi tertinggi sebanyak 68 (29,4\%). Hal ini menunjukkan bahwa pemakaian tanda koma merupakan bagian yang sulit bagi mahasiswa. Sementara itu, kesalahan penulisan gabungan kata frekuensi kemunculannya paling rendah sebanyak $8(3,4 \%)$. Artinya, bagian ini tidak terlalu sulit bagi mahasiswa meskipun tidak dapat dikatakan bagian itu mudah sebab masih terjadi kesalahan. Bagian yang mudah adalah bagian yang tidak mengandung kesalahan. 
$\begin{array}{ccc}\text { Jika } & \text { dilihat dari } & \text { aspek } \\ \text { persebarannya } & \text { (dengan } & \text { tidak }\end{array}$ mempertimbangkan frekuensi kesalahan), kesalahan pemakaian tanda baca terdapat pada seluruh makalah (100\%), kesalahan pemakaian huruf terdapat pada 13 makalah (62\%), dan kesalahan penulisan kata terdapat pada seluruh makalah (100\%). Persentase persebaran tersebut cukup tinggi karena lebih dari $50 \%$, bahkan sampai $100 \%$.

\section{Faktor Penyebab Kesalahan}

Kesalahan berbahasa dapat dibedakan atas kesalahan antarbahasa (interlanguage errors) dan kesalahan intrabahasa (intralingual errors) Tarigan, 1990:85). Kesalahan antarbahasa disebabkan oleh interferensi bahasa lain. Sementara itu, kesalahan intrabahasa ialah kesalahan yang merefleksikan ciri-ciri umum kaidah yang dipelajari, seperti kesalahan generalisasi, penerapan kaidah yang tidak sempurna, dan kegagalan mempelajari kondisi-kondisi penerapan kaidah.

Mengacu pada pendapat di atas, kesalahan penggunaan ejaan dalam makalah mahasiswa tergolong ke dalam kesalahan intrabahasa. Kesalahan penggunaan ejaan seperti yang telah dideskripsikan sebelumnya termasuk kesalahan intrabahasa. Kesalahan intrabahasa tersebut terutama disebabkan oleh ketidaktahuan mahasiswa akan pembatasan kaidah dan penerapan kaidah yang tidak sempurna. Dalam penelitian ini kaidah yang dimaksud adalah kaidah ejaan yang disempurnakan (EYD).

\section{Penutup}

Ada beberapa jenis kesalahan penggunaan ejaan dalam makalah mahasiswa. Kesalahan itu meliputi kesalahan dalam pemakaian tanda baca, pemakaian huruf, dan penulisan kata. Kesalahan pemakaian tanda baca terlihat pada kesalahan pemakaian tanda koma (,) dan tanda titik (.). Kesalahan pemakaian huruf berkaitan dengan pemakaian huruf miring. Kesalahan penulisan kata ditemukan pada penulisan gabungan kata, kata berimbuhan, kata depan, partikel, dan lambang bilangan.

Dengan memperhatikan frekuensi dan persebaran kesalahan dapat disimpulkan bahwa kesalahan penggunaan ejaan dalam makalah mahasiswa merupakan bentuk kesalahan yang serius dan perlu mendapat perhatian. Kesalahankesalahan tersebut tergolong ke dalam kesalahan intrabahasa. Jika dicermati kesalahan intrabahasa tersebut disebabkan oleh ketidaktahuan mahasiswa pada kaidah dan penerapan kaidah yang tidak sempurna. Hal ini mengisyaratkan bahwa mahasiswa belum memahami ejaan yang disempurnakan (EYD), baik dari segi kaidahnya maupun penerapannya.

\section{Daftar Pustaka}

Ahmadi, dkk. 2011.Menulis Ilmiah: Buku Ajar MPK Bahasa Indonesia. Surabaya: Unesa University Press.

Arifin, E. Zaenal dan Tasai, S. Amran. 2009. Cermat Bertbahasa Indopnesia. Jakarta: Akademika Pressindo.

Baradja, M.F.1981.Peranan Analisis Kontrastif.Jakarta:P3G

Brown, H., Douglas. 2004. Principles of Language Teaching And Learning. New Jersey: Prentice Hall Inc.

Corder, S.P. 1982. Error Analysis and Interlanguage. Oxford:

OxfordUniversity Press. 1985. The Significance of Learner's Errors. Oxford: Oxford University Press.

Dulay, Heidi, Mariana Burt, dan Stephen Krashen. 1982. Language Two. Oxford: OxfordUniversity Press. 
Putrayasa, Ida Bagus. 2007. Kalimat Efektif. Bandung: PT Refika Aditama

Saadiyah Darus and Kaladevi Subramaniam. 2009. "Error Analysis of the Written English Essays of Secondary School Students in Malaysia : A Case Study". European Journal of Social Sciences - Volume 8, Number 3.

Soedradjad, R. Bahasa Indonesia dalam Tulisan

Ilmiah.http://elcom.umy.ac.id/elscho ol/muallimin-

muhammadiyah/xfile.php/satu/ materi/bahasa-indonesia/bab-3bahasa.pdf. diunduh 9 Agustus 2012 pukul 10.00.

Suwandi, Sarwiji 2008. Serba Linguistik (Mengupas Pelbagai Praktik Berbahasa). Surakarta: LPP UNS.

Tarigan, Henry Guntur dan Djago Tarigan. 1990. Pengajaran Analisis Kesalahan Berbahasa. Bandung : Angkasa.

Yulianto, Bambang. 2003. "Segi-Segi Penulisan Laporan". Surabaya: Makalah Seminar Nasional Penulisan Karya Ilmiah. 